invariably moves in the opposite direction to the $\mathrm{PacO}_{\text {. }}$. This inverse relationship points to the possible importance of considering a fall in the $\mathrm{PaCO}_{2}$-very closely related to the alveolar $\mathrm{PCO}_{2}-$ causing a rise in $\mathrm{PAO}_{2}$ and $\mathrm{PaO}_{2}$, as may be seen in the hyperpnoea of renal failure acidosis.

\section{Discussion}

From the results presented it is clear that the abdominal filling with peritoneal dialysate interferes with pulmonary gas exchange. Two-litre cycles, not surprisingly, have a greater effect than a 1-litre cycle. The most important and often the only change is on the arterial $\mathrm{PaO}_{2}$. There was no known pulmonary disease in any of the patients studied, but in all cases there was a reduction of arterial $\mathrm{PaO}_{2}$ when the dialysate had been run into the abdomen, and equally there was an increase in $\mathrm{PaO}_{2}$ when the dialysate had been run out. The changes in $\mathrm{PaCO}_{2}$ were less consistent but in most cases moved in the opposite direction to that of $\mathrm{PaO}_{2}$. These findings would be consistant with some degree of basal pulmonary collapse during the presence of dialysate in the abdomen which was reversed when the abdomen was empty.

Berlyne (1966) ascribed the infective pulmonary complications of peritoneal dialysis to plugs of mucus being drawn down into the re-expanding pulmonary bases after temporary collapse during abdominal filling. In our own series infective pulmonary complications were not obvious but the rapid reversal of the arterial gas exchanges on emptying the abdomen cannot be accepted as an argument against Berlyne's hypothesis explaining the infective complications. Most patients with either acute or chronic renal failure are anaemic, and a reduction of arterial oxygen tension may be of considerable importance. With the evidence that the larger cycle tends to cause a greater reduction in $\mathrm{PaO}_{2}$ suggests that 1-litre cycles should be more frequently used, as was suggested by Berlyne for other reasons. Unlike the observations on anaesthesia in patients with metabolic acidosis due to renal failure peritoneal dialysis causes only minor changes in $\mathrm{PaCO}_{2}$ and it is unlikely that the metabolic acidosis is aggravated by this procedure, the more so as the dialysing fluid will contain acetate or lactate. Nor will the possibility of a sudden hyperkalaemia be of significance, as potassium is being removed during the dialysis.

We would like to thank Professor K. W. Donald, Dr. D. C. Flenley, and other members of the department of medicine, University of Edinburgh, for their helpful advice. Determinations of plasma potassium were performed by courtesy of Dr. G. A. Rose. Helpful co-operation from members of the department of anaesthetics of the Royal College of Surgeons made the first study possible. For charts and photographs we are indebted to the departments of medical illustration and photography of the Institute of Urology.

\section{References}

Benzinger, T. (1937). Ergebnisse der Physiologie, biologischen Chemie und experimentellen Pharmakologie, 40, 1.

Berlyne, G. M., Lee, H. A., Ralston, A. J., and Woolcock, J. A. (1966) Lancet, 2, 75 .

Compamanes, C. I., Boyan, C. P., Weldon Belleville, J., and Howland, W. S. (1959). Anaesthesia and Analgesia, 38, 283.

Finn, R., and Jowett, E. W. (1970). British Medical fournal, 2, 94.

Goott, B., Rosenberg, J. C., Lillehei, R. C., and Miller, F. A. (1960). fournal of Thoracic and Cardiovascular Surgery, 40, 625.

Holmes, J. H., Nakamoto, S., and Sawyer, K. C., jun. (1958). Transactions of the American Society for Artificial Internal Organs, 44, 16.

Katz, J., Kountz, S. L., and Cohn, R. (1967). Anaesthesia and Analgesio Current Research, 46, 609.

Le Vine, D. S., and Virtue, R. W. (1964). Canadian Anaesthetists' Society fournal, 4, 425 . Löfström, B. (1967). Scandinavian fournal of Urology and Nephrology,

Paton, W. D. M. (1956). British fournal of Anaesthesia, 28, 470.

Powell, J. N. (1970). British fournal of Anaesthesia, 42, 806.

Roth, F., and Wütrich, H. (1969). British fournal of Anaesthesia, 41, 311.

\title{
Study of the Secular Trend in Asbestos Bodies in Lungs in London 1936-66
}

\author{
CHANG-HYUN UM
}

British Medical fournal, 1971, 2, 248-252

\section{Summary}

Thick sections ( $30 \mu$ unstained) cut from blocks of lung tissue from 100 consecutive necropsies for the years 1936, 1946, 1956, and 1966 at the Archway Hospital, London, have been searched for asbestos bodies. The incidence rose progressively-0, 3, 14, and $20 \%$ respectively. The rise was not explained by the increasing age of death in the later years or by the likely effects of changes in the areas within London in which the deaths occurred. There was no similar increase in the incidence of other bodies in the lungs which might be mistaken for asbestos bodies. The rising incidence is shown to fit reasonably with a model based on the hypothesis that the risk of inhaling asbestos increases in relation to the cumu-

M.R.C. Pneumoconiosis Unit, Llandough Hospital, Penarth, Glamorgan CF6 $1 \times$ W

CHANG-HYUN UM, M.D., D.I.H., Member, Scientific Staff (Present address: c/o Department of Pathology, Brompton Hospital, London S.W.3) lative total of asbestos imported into the country from 1910 onwards. The rising incidence does not fit a model in which the risk depends simply on the current level of asbestos imports.

\section{Introduction}

Many recent studies have shown the high proportion of lungs in which asbestos bodies can be found (Thomson et al., 1963; Elmes et al., 1965; Meurman, 1966; Rotzsch, 1967; Ashcroft, 1968; Dicke and Naylor, 1969). Apart from Selikoff and Hammond (1970), no attempt has been made to see whether the proportion of lungs with such bodies has changed over the years as the amount of asbestos used has increased. Such a study might show whether there has been an increase in environmental pollution by asbestos fibres as detected by their retention in the lungs. An opportunity to make such a study was provided by the completeness of the pathological records at the Central Histological Laboratory of the Arch- 
way Hospital, London. This laboratory served all former L.C.C. hospitals up to the time of the National Health Service in 1948, and has since served a small group of hospitals. Some of the findings in this investigation were included in a paper given at the Pneumoconiosis International Conference held in Johannesburg in 1969 (Pooley et al., 1970).

\section{Material and Methods}

For the years 1936, 1946, 1956, and 1966 respectively 127, 100, 100 , and 100 consecutive necropsies on patients over the age of 20 in which there was a block of lung tissue available were chosen. The site and lobe of the lung from which a block happened to be taken varied or was not recorded. This would not appear to affect the results, because it has been fairly well established that asbestos bodies are evenly distributed within the lung (Dicke and Naylor, 1969; Bell and Elmes, 1971).

Sections of $5 \mu$ and one of $30 \mu$ were cut from the blocks; one of the $5 \mu$ sections was stained with haematoxylin and eosin. The sections were randomized so that the observer was unaware of what year the material came from, and the order of inspection was such as to avoid bias due to changes of skill of the observer with time.

The slide holder of the microscope was modified to take two slides, one superimposed on the other, the lower one with a grid to facilitate scanning, recording, and the measurement of the area of the section in which a search for asbestos bodies was made. A detailed description of this device, which may be called a "concurrent" scanner-finder, will be given elsewhere. The slides were systematically searched (using a 16-mm objective) and the position and type of asbestos body plotted on graph paper or each slide. Confirmation was made with a 4-mm objective. Ordinary light microscopy was used with the iris diaphragm adjusted to render the grid just visible.

An asbestos body was recorded, taking into account shape, size, colour, and appearance of the central core. Notes were kept of other bodies that superficially resembled asbestos bodies but they were found to show no secular trend and were therefore ignored.

For the positive cases an estimate was made of the number of asbestos bodies per unit volume of lung tissue, taking into account the area and thickness by which the bodies were protected. The length of the bodies was also recorded.

\section{Results}

The age and sex distribution of the lungs examined and the number in which asbestos bodies were detected for material from 1936 to 1966 are shown in Table I. The percentages of positive were $0,3,14$, and 20 respectively. The mean area of sections scanned per case was not quite the same in each decade (Table II), but this could cause only small changes

\begin{tabular}{|c|c|c|c|c|}
\hline \multirow{2}{*}{$\begin{array}{l}\text { No. of Asbestos } \\
\text { Bodies Found }\end{array}$} & \multicolumn{4}{|c|}{$\begin{array}{l}\text { Density of Each Positive Case with Given } \\
\text { Number of Asbestos Bodies }\end{array}$} \\
\hline & 1936 & 1946 & 1956 & 1966 \\
\hline $\begin{array}{r} \\
2 \\
3 \\
4 \\
10 \\
\end{array}$ & & $\begin{array}{l}158 \\
200 \\
237\end{array}$ & $\begin{array}{l}158 \\
158 \\
158 \\
158 \\
158 \\
158 \\
163 \\
163 \\
163 \\
169 \\
315\end{array}$ & $\begin{array}{r}158 \\
158 \\
158 \\
158 \\
169 \\
175 \\
178 \\
178 \\
179 \\
188 \\
192 \\
192 \\
214 \\
222 \\
237 \\
238 \\
315 \\
770 \\
630 \\
1,436 \\
\end{array}$ \\
\hline $\begin{array}{l}\text { No. of Asbestos } \\
\text { bodies in section } \\
\text { examined }\end{array}\left|\begin{array}{l}\text { Mean } \\
\text { Median } \\
\text { Mode }\end{array}\right|$ & $\begin{array}{l}0 \\
1 \\
1\end{array}$ & $\begin{array}{l}1 \\
1 \\
1\end{array}$ & $\begin{array}{l}1 \cdot 2 \\
1 \\
1\end{array}$ & $\begin{array}{l}1_{1}^{1 \cdot 75} \\
1\end{array}$ \\
\hline Mean density & & $198 \cdot 3$ & 225.4 & $340 \cdot 2$ \\
\hline $\begin{array}{l}\text { Mean area of section } \\
\text { in } \mathrm{mm}^{2}\end{array}$ & $198 \cdot 2$ & $189 \cdot 6$ & $207 \cdot 9$ & $179 \cdot 7$ \\
\hline $\begin{array}{l}\text { Mean area of section } \\
\text { for whole series }\end{array}$ & \multicolumn{4}{|c|}{$194 \cdot 2$} \\
\hline
\end{tabular}

- Density means the number of asbestos bodies per unit volume $\left(\mathrm{cm}^{3}\right)$ estimated from observation of a given section.

in the trend. The average number of asbestos bodies in a section also increased slightly from 1.0 in 1946 to 1.2 in 1956 and 1.75 in 1966. The number of asbestos bodies per unit volume of lung tissue examined increased progressively from 1946 to 1966. The frequency distribution of the length of the asbestos bodies showed that none less than $20 \mu$ was

TABLE 1-Sex and Age-specific Distribution of Lung Sections examined with Results and their Analysis

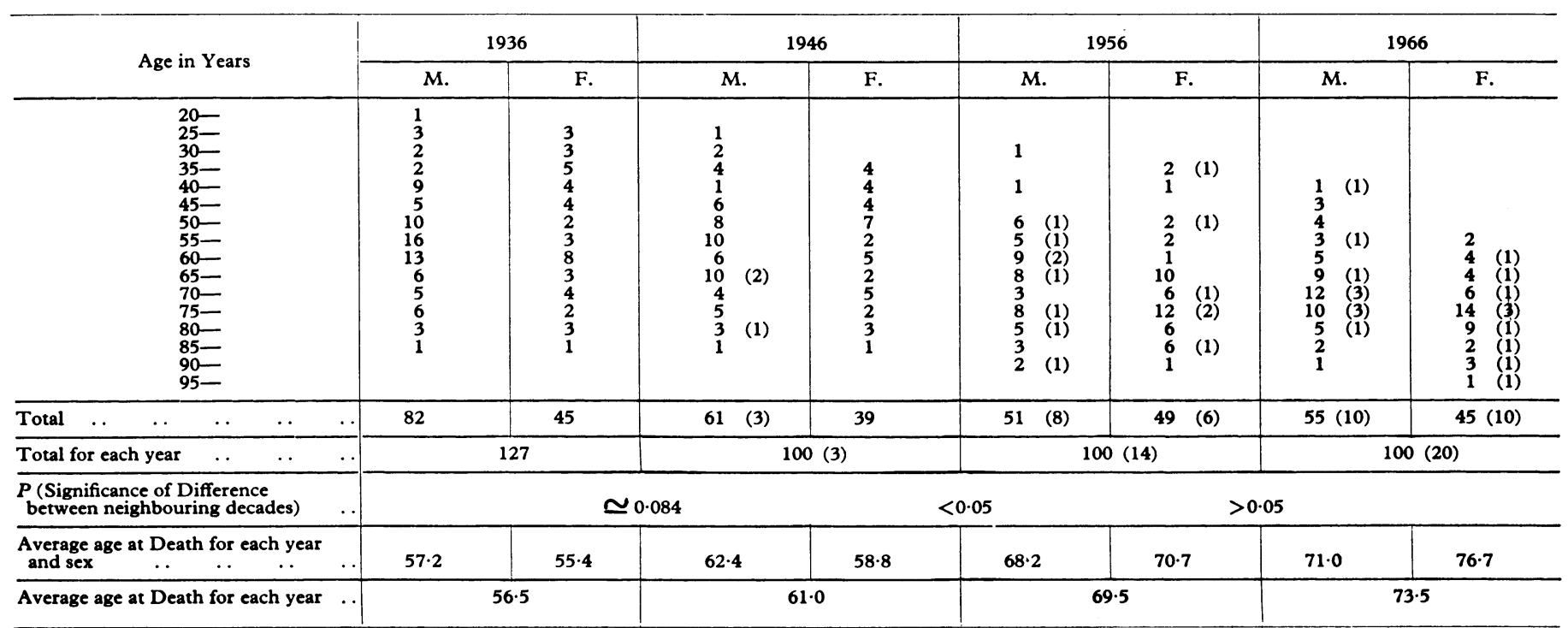

Number of positives are given in parentheses. 
recorded, the commonest length being $60 \mu$ with a few bodies above $150 \mu$ showing a bimodal distribution.

\section{EFFECTS OF AGE}

The selection of material from consecutive necropsies resulted as expected in an unmatched sex and age distribution of cases. Over the period of study the average age at death increased in the general public but less than in the series as given in Table $I$, and this must represent some change in the selection of cases coming to necropsy over the years.

TABLE III-Secular Changes in Incidence of Asbestos Bodies by Age Group

\begin{tabular}{l|c|c|c|c|c|c|c|c|c|c}
\hline \multirow{2}{*}{} & \multicolumn{2}{|c|}{$50-59$} & \multicolumn{2}{c|}{$60-69$} & \multicolumn{2}{c|}{$70-79$} & \multicolumn{2}{c|}{$80-89$} & \multicolumn{2}{c}{$90+$} \\
\cline { 2 - 9 } & No. & Pos. & No. & \multicolumn{1}{|c|}{ Pos. } & No. & \multicolumn{1}{c|}{ Pos. } & No. & Pos. & No. & Pos. \\
\hline 1936 & 31 & 0 & 30 & 0 & 17 & 0 & 8 & 0 & & \\
1946 & 27 & 0 & 23 & $2(8 \cdot 7)$ & 16 & 0 & 8 & $1(12 \cdot 5)$ & & \\
1956 & 15 & $3(20)$ & 28 & $3(10 \cdot 6)$ & 29 & $4(13 \cdot 8)$ & 20 & $2(10 \cdot 0)$ & 3 & $1(33)$ \\
1966 & 9 & $1(11)$ & 22 & $3(13 \cdot 7)$ & 42 & $10(23 \cdot 8)$ & 18 & $3(16 \cdot 6)$ & 5 & $2(40)$ \\
\hline
\end{tabular}

Percentages are given in parentheses.

For each 10-year age group from 50 to $90+$, though the numbers are small, there is in general a clear and graded increase of percentage of positives through the period from 1936 to 1966 (Table III). Thus it appears that the increased age at death in the later years is not the explanation for the rising prevalence over the period 1936 to 1966.

\section{CUMULATED EFFECTS OF IMPORTED ASBESTOS}

As it is believed that these bodies represent the accumulation in the lung of an environmental exposure to asbestos it seemed reasonable to attempt to relate this rising incidence to figures for imports of asbestos of all kinds into the United Kingdom. These were provided by the Asbestos Information Committee for various dates from 1920. The figures suggested that the imports rose nearly linearly from 20,000 tons in 1920 to about 150,000 tons in 1965. An attempt was made to fit the observed prevalence of asbestos bodies in the lungs to a linearly increasing risk of inhaling asbestos. This failed; it would require more cases in 1936 and fewer in 1966. However, since the cases were from the general population and not from asbestos workers, it might be more reasonable to suppose that the risk increased with the cumulated amount of asbestos imported, all past imports in the form of manufactured articles being a source of fibres for inhalation. On this basis a satisfactory fit was obtained.

A simple mathematical argument based on a linear increase of imports from an arbitrary zero in 1910 leads to a probability

$$
\mathrm{p}=1-\exp \left(-k \mathrm{t}^{3}\right)
$$

for person born before 1910, and

$$
p=1-\exp \left\{-k\left(t^{3}-t_{0}{ }^{3}\right)\right\}
$$

for a person born $t_{0}$ years after 1910, being found to have asbestos bodies in the lungs on dying $t$ years after 1910, $k$ being a constant. Maximum likelihood estimation of $k$ gave similar estimates for males and females and a combined estimate of $(1.17+0.19) \times 10^{-6}$. Table IV shows the fair agreement between observed and expected positives for asbestos bodies given by this model, though evidently the rate of increase of cases given by the model is not so steep as it should be. The model, however, seems an adequate and interpretable means of summarizing the findings. It implies, for instance, that $22.5 \%$ of persons above the age of 40 would have detectable asbestos bodies in their lungs by 1970 and $33 \%$ by 1980 . It is clear that the clinical significance of these implications must be elucidated.

\section{SOURCE OF EXPOSURES}

An attempt to use other information in the records at the Archway Hospital and elsewhere to identify the occupations of the individuals in the groups studied failed. But it was thought necessary to check whether the rising prevalence of asbestos bodies in the lungs over the period studied might be the result of differences in the areas from which the pathological material came. The results of plotting the distribution of hospitals from which the cases came in 1936 and in 1966 are

\begin{tabular}{|c|c|c|c|c|c|}
\hline \multirow{2}{*}{$\begin{array}{l}\text { Date of } \\
\text { Death }\end{array}$} & \multirow{2}{*}{ Date of Birth } & \multirow{2}{*}{ Sex } & \multirow{2}{*}{$\begin{array}{l}\text { No. of } \\
\text { Cases }\end{array}$} & \multicolumn{2}{|c|}{ No. Positive } \\
\hline & & & & Observed & Expected \\
\hline \multirow[t]{2}{*}{1936} & $\begin{array}{l}1910 \text { or earlier }\{\} \\
1912\end{array}$ & $\begin{array}{l}\text { M. } \\
\text { F. } \\
\text { M. }\end{array}$ & $\begin{array}{r}81 \\
45 \\
1\end{array}$ & $\begin{array}{l}0 \\
0 \\
0\end{array}$ & $\begin{array}{l}1.65 \\
0.92 \\
0.02\end{array}$ \\
\hline & & Total & 127 & 0 & 2.59 \\
\hline \multirow[t]{2}{*}{1946} & $\begin{array}{l}1910 \text { or earlier } \\
1911 \\
1915 \\
1917\end{array}$ & $\begin{array}{l}\text { M. } \\
\text { F. } \\
\text { M. } \\
\text { M. }\end{array}$ & $\begin{array}{r}58 \\
39 \\
1 \\
1 \\
1\end{array}$ & $\begin{array}{l}3 \\
0 \\
0 \\
0 \\
0\end{array}$ & $\begin{array}{l}3.08 \\
2.07 \\
0.05 \\
0.05 \\
0.05\end{array}$ \\
\hline & & Total & 100 & 3 & $5 \cdot 30$ \\
\hline \multirow[t]{2}{*}{1956} & $\begin{array}{l}1910 \text { or earlier } \\
1913 \\
1919 \\
1921 \\
\end{array}$ & $\begin{array}{l}\text { M. } \\
\text { F. } \\
\text { M. } \\
\text { F. } \\
\text { M. }\end{array}$ & $\begin{array}{r}49 \\
46 \\
1 \\
1 \\
2 \\
1 \\
\end{array}$ & $\begin{array}{l}8 \\
5 \\
0 \\
0 \\
1 \\
0 \\
\end{array}$ & $\begin{array}{l}5 \cdot 28 \\
4.95 \\
0 \cdot 11 \\
0.11 \\
0.21 \\
0.11\end{array}$ \\
\hline & & Total & 100 & 14 & $10 \cdot 77$ \\
\hline \multirow[t]{3}{*}{1966} & $\begin{array}{l}1910 \text { or earlier } \\
1911 \\
1912 \\
1915 \\
1917 \\
1920 \\
1921\end{array}$ & $\begin{array}{l}\text { M. } \\
\text { F. } \\
\text { M. } \\
\text { M. } \\
\text { M. } \\
\text { M. } \\
\text { M. }\end{array}$ & $\begin{array}{r}47 \\
45 \\
2 \\
1 \\
1 \\
2 \\
1 \\
1 \\
\end{array}$ & $\begin{array}{r}9 \\
10 \\
0 \\
0 \\
0 \\
0 \\
0 \\
1 \\
\end{array}$ & $\begin{array}{l}8 \cdot 74 \\
8 \cdot 36 \\
0 \cdot 37 \\
0 \cdot 19 \\
0 \cdot 19 \\
0 \cdot 37 \\
0 \cdot 18 \\
0 \cdot 18 \\
\end{array}$ \\
\hline & & Total & 100 & 20 & 18.58 \\
\hline & & Grand Total & 427 & 37 & $37 \cdot 24$ \\
\hline
\end{tabular}

TABLE IV-Observed and Expected Positives for Asbestos Bodies 


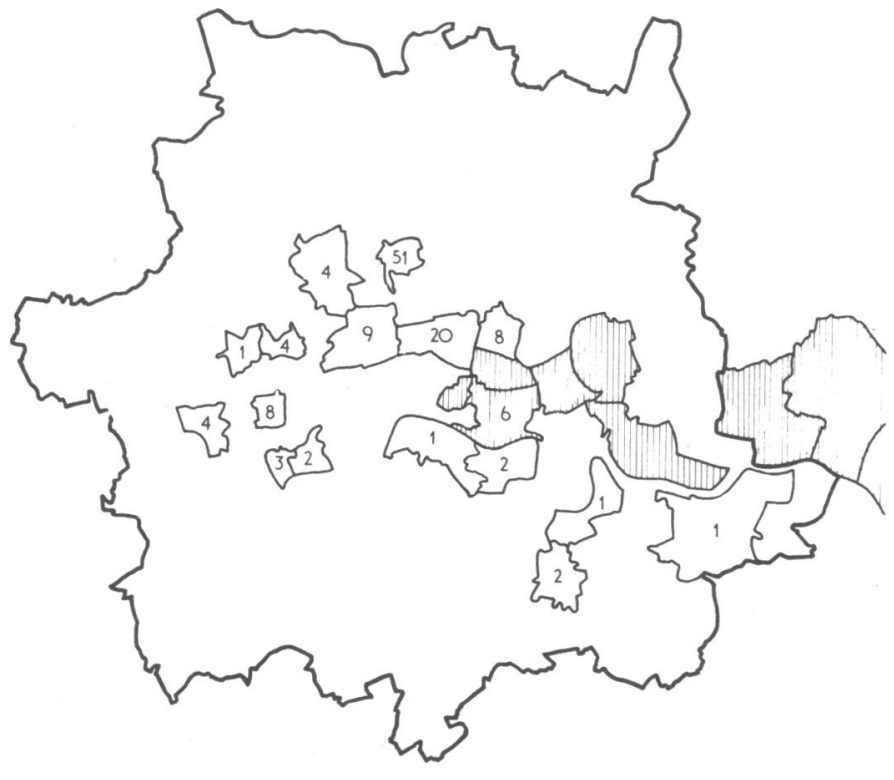

FIG. 1-Distribution of cases in 1936 in relation to London postal districts in which L.C.C. hospitals were sited. Hatched areas: regions in which asbestos factories were sited.

shown in Figs. 1 and 2. As was expected there was a major change which occurred at the time of the introduction of the National Health Service in 1948. In addition, Figs. 1 and 2 show the areas in which it was known that asbestos factories existed at that time.

\section{Conclusion:}

By comparing Figs. 1 and 2 it is clear that in the earlier period there was a greater chance of men who had worked and lived and died in hospitals near the factories known to be using asbestos being included in the sample drawn from the Archway records than at the later period, when all the cases came from hospitals much less widely distributed through the L.C.C. area and well away from the regions in which the asbestos factories existed. Thus it is probable that the material examined for the periods 1956 and 1966 was if anything biased compared with the two previous groups away from containing those who had worked in asbestos manufacturing industry. If anything, therefore, the altered prevalence over the period 1936 to 1966 is likely to have been an underestimate rather than an overestimate of the general trend.

My thanks are due to Dr. P. C. Meyer, Director of the Pathology Institute of the Whittington Hospital, London N.19, for allowing me to use his materials; to Dr. J. C. Gilson, Dr. J. C. Wagner,

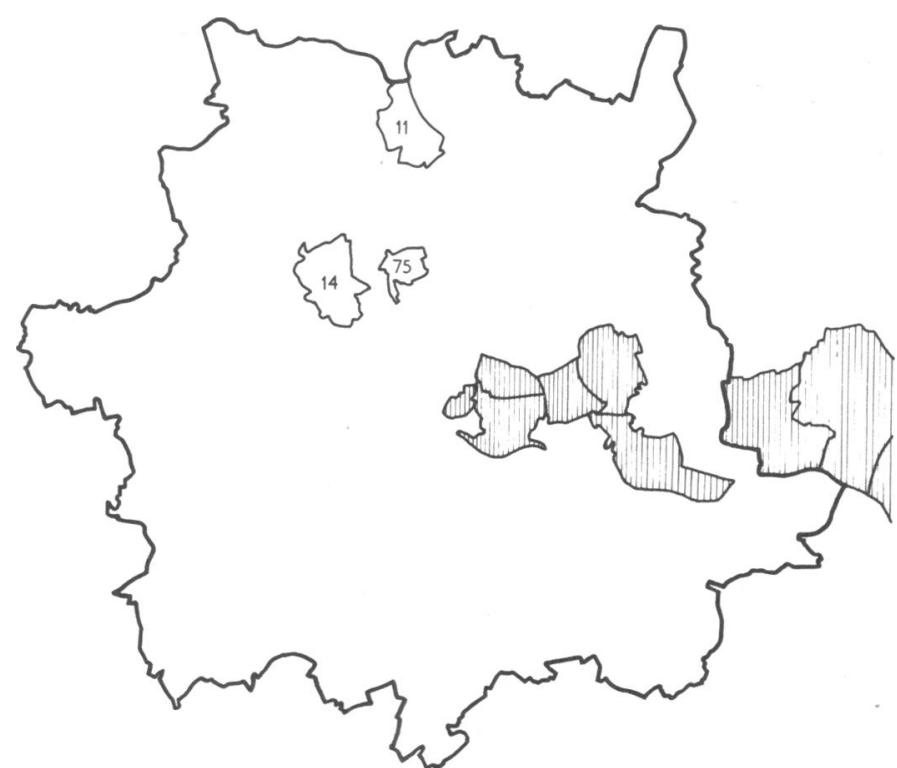

FIG. 2-Distribution of cases in 1966 in relation to London postal districts. Hatched area: regions in which asbestos factories were sited.

and Mr. P. D. Oldham, of the M.R.C. Pneumoconiosis Unit, Penarth, Glamorganshire, for their advice, help, and encouragement throughout the work; to Dr. K. F. W. Hinson for his advice and for providing working facilities in his department of pathology, the Brompton Hospital, London; and to Mr. T. Buckley for technical help.

This work was financed by a grant from the International Agency for Research on Cancer.

\section{References}

Ashcroft, T. (1968). British Medical fournal, 1, 614.

Bell, D., and Elmes, P. C. (1971). In Proceedings of the Second International Conference on the Biological Effects of Asbestos, Dresden, 22-25 April, 1968. In press.

Dicke, T. E., and Naylor, B. (1969). Diseases of the Chest, 56, 122

Elmes, P. C., McCaughey, W. T. E., and Wade, O. L. (1965). British Medical fournal, 1, 350 .

Meurman, L. (1966). Acta Pathologica et Microbiologica Scandinavica, Suppl. No. 181

Pooley, F. D., Oldham, P. D., Um, Chang-hyun, and Wagner, J. C. (1970). In Pneumoconiosis. Proceedings of the International Conference, fohannesburg, 1969, ed. H. A. Shapiro, p. 108, Cape Town, Oxford University Press.

Rotzsch, E. (1967). Zentralblatt für allgemeine Pathologie und pathologische Anatomie, 110, 264.

Selikoff, I. J., and Hammond, E. C. (1970). In Pneumoconiosis. Proceedings of the International Conference, fohannesburg, 1969, ed. H. A. Shapiro, p. 99. Cape Town, Oxford University Press.

Thomson, J. G., Kaschula, R. O. C., and MacDonald, R. R. (1963). South African Medical fournal, 37, 77. 